\title{
Serum autoantibodies and the diagnosis of type-1 autoimmune hepatitis in Italy: a reappraisal at the light of hepatitis $C$ virus infection
}

\author{
F Cassani, L Muratori, P Manotti, M Lenzi, M Fusconi, G Ballardini, L Selleri, U Volta, \\ D Zauli, R Miniero, F B Bianchi
}

\begin{abstract}
Antinuclear antibodies with the homogeneous pattern (ANA-H) and smooth muscle antibodies with antiactin specificity (SMA-AA) are regarded as the serum markers of type-1 autoimmune chronic hepatitis. Their diagnostic relevance, however, has been questioned recently after the detection of signs of hepatitis C virus infection in autoimmune chronic hepatitis patients. To further evaluate this point, antihepatitis $C$ virus antibodies were sought by two second generation assays (ELISA 2 and RIBA 2) in 100 Italian patients with chronic liver disease of unknown aetiology, including 46 with (autoimmune chronic hepatitis) and 54 without the above antibodies (cryptogenic). By ELISA 2, antihepatitis C virus, although significantly prevalent in cryptogenic $(83 \%)$, were found also in a substantial proportion of autoimmune chronic hepatitis patients $(46 \%)(p<0.0001)$, their occurrence was confirmed by RIBA 2 in almost all cases ( $96 \%$ and $86 \%$, respectively). Autoimmune patients with either ANA-H or SMA-AA exhibited similar antihepatitis C virus prevalences ( $59 \%$ and $52 \%$, respectively); by contrast, the eight cases positive for both the autoantibodies were consistently antihepatitis $C$ virus negative. These findings confirm that in countries with high hepatitis $\mathbf{C}$ virus circulation (like Italy) an overlap between autoimmune chronic hepatitis and hepatitis $\mathbf{C}$ virus infection, reflected by 'true' antihepatitis $C$ virus antibodies, does occur. The detection of ANA-H or SMA-AA, in fact, identifies chronic liver disease patients with a relatively low prevalence of antihepatitis $C$ virus, but does not exclude hepatitis $C$ virus infection. Positive findings for both ANA-H and SMAAA, however, is an appropriate marker for hepatitis $C$ virus free 'primary' autoimmune chronic hepatitis.
\end{abstract}

(Gut 1992; 33: 1260-1263)

Antinuclear and smooth muscle antibodies are commonly regarded as the most reliable positive markers of type- 1 autoimmune chronic hepatitis in cases of chronic liver disease of unknown aetiology.' Both antibodies are a largely heterogeneous family. It has been repeatedly reported that smooth muscle antibodies of autoimmune chronic hepatitis are directed to cell actin. Using immunomorphological techniques, smooth muscle antibodies with antiactin specificity visualise the microfilamentous component of the cell cytoskeleton.' The relevant target antigen of antinuclear antibodies associated with autoimmune chronic hepatitis is unknown, the available information being that it is different from ds-DNA and 'rheumatological' extractable nuclear antigens of 'rheumatic diseases'. Both reactivities are in fact uncommon in autoimmune chronic hepatitis. ${ }^{3+}$ It has been claimed that antinuclear antibodies of autoimmune chronic hepatitis reacts with an antigen which is homogeneously distributed within the nucleus and thus gives a 'homogeneous' pattern (ANA-H) of positivity by immunofluorescence..$^{25}$ Antibodies specifically reacting with nuclear components of peripheral blood polymorphs have also been described.

A number of clinical and biochemical features (female predominance, associated autoimmune disorders, high serum transaminase values at presentation, HLA-DR3 haplotype) are significantly prevalent in autoimmune chronic hepatitis, but of limited diagnostic value. Even the favourable response to a course of steroids has some diagnostic use after only two to three months of treatment as an 'ex juvantibus' criterion.

Other autoantibodies directed against cytoskeletal antigens different from actin as well as antinuclear antibodies giving a 'speckled' pattern of positivity, are found at a low titre $(<1: 100)$ in cryptogenic, viral, and alcoholic chronic liver disease.

Tests able to identify antibodies directed against peptides of a virus (hepatitis $C$ virus$\mathrm{HCV}$ ) responsible for most cases of posttransfusion and community acquired non- $A$, non-B hepatitis have recently become available.? Using the first generation Ortho-Chiron ELISA, which allows detection of antibodies against recombinant non-structural hepatitis $\mathrm{C}$ virus peptides, $58 \%$ of Italian autoimmune chronic hepatitis cases, defined as reported above - that is, positive for ANA-H and/or SMA-AA - turned

TABLE I Clinical, biochemical and histological parameters of the chronic liver disease (CLD) patients studied. $A I-C H=$ autoimmune chronic hepatitis

\begin{tabular}{lcc}
\hline & $\begin{array}{c}\text { Type-1 AI-CH } \\
(46)\end{array}$ & $\begin{array}{l}\text { Cryptogenic (LLD) } \\
(54)\end{array}$ \\
\hline Male/female & $7 / 39$ & $8 / 46$ \\
Age (yr) & $59(15-81)$ & $60(16-82)$ \\
GOT (U/l) & $51(15-620)$ & $+5(10-154)$ \\
Gamma-globulins (g/dl) & $2 \cdot 13(0 \cdot 88-4 \cdot 27) \dagger$ & $1 \cdot 71(0 \cdot 9+-3 \cdot 45)^{\star}$ \\
Cirrhosis & $18 / 29$ & $32 / 43$ \\
\hline
\end{tabular}

^Patients with histological evidence of cirrhosis/patients who underwent liver biopsy; $\nmid$ Type-1 AI-CH vs cryptogenic (CI.D): $<0 \cdot 05$ (Wilcoxon).

Values are expressed as median (range). Normal ranges of glutamic oxalo acetic transaminase (GOT) and gamma globulins are $0-20 \mathrm{U} / \mathrm{l}$ and $0 \cdot 8-1 \cdot 5 \mathrm{~g} / \mathrm{dl}$, respectively. 
out to be also positive for antihepatitis $\mathrm{C}$ virus. ${ }^{8}$ This confirmed a previous report from Spain. ${ }^{9}$

In order to test the diagnostic relevance of ANA-H and SMA-AA as markers of type-1 autoimmune chronic hepatitis we applied two commercially available second generation tests for detecting antihepatitis $C$ virus antibodies: an ELISA and an immunoblot assay (both from Ortho-Chiron), which detect antibodies to nonstructural and structural hepatitis $C$ virus recombinant peptides. As controls, cryptogenic cases of chronic liver disease - that is, without ANA-H or SMA-AA, were similarly studied.

\section{Methods}

\section{PATIENTS AND SERA}

Serum samples from 100 patients with chronic liver disease of unknown aetiology were studied: 46 with autoimmune chronic hepatitis and 54 with cryptogenic chronic liver disease. The diagnosis of chronic liver disease was made by accepted clinical, serological and histological criteria. ${ }^{10}$ Clinical and biochemical parameters are reported in Table $I$. Hepatitis B virus infection was excluded on the basis of radioimmunoassay negativity for serological markers (HBsAg, $\mathrm{HBeAg}$, anti $\mathrm{HBs}$, anti $\mathrm{HBc}$, and anti $\mathrm{HBe})$. In the cases studied alcohol intake was never higher than $50 \mathrm{~g} /$ day. Alpha-1 antitrypsin deficiency and Wilson disease were excluded by determining serum concentrations of alpha-1 antitrypsin and ceruloplasmin, respectively. Intake of potentially hepatotoxic drugs, intravenous drug addiction and previous blood transfusions were ruled out in all patients. All autoimmune patients exhibited serum ANA-H and/or SMA-AA; they were in a different phase of treatment with methylprednisolone at the moment of antihepatitis $\mathrm{C}$ virus testing. All cryptogenic patients were negative for ANA-H, SMA-AA as well as liver-kidney microsomal antibody.

\section{AUTOANTIBODY TESTING}

Sera, diluted 1:40, were tested by immunofluorescence using both cryostat tissue (rat liver, stomach, and kidney) sections and HEp-2 cell cultures (Kallestad, Austin, Texas, USA) as substrates. Liver sections of rats chronically intoxicated with phalloidin were also used, as previously described." Antibodies to muscle actin were also searched for by counterimmunoelectrophoresis using rabbit muscle actin as antigen." Sera were scored as positive for

TABLE II Antihepatitis $C$ virus antibodies detected by ELISA 2 and RIBA 2 in type-1 autoimmune chronic hepatitis $(A I-C H)$ and cryptogenic chronic liver disease (CLD)

\begin{tabular}{|c|c|c|c|}
\hline & \multicolumn{2}{|l|}{ Elisa 2} & \multirow{2}{*}{$\begin{array}{l}R I B A 2 \\
\text { Anti-HCV+ }\end{array}$} \\
\hline & Anti-HCV+ & $O D>3$ & \\
\hline $\begin{array}{l}\text { AI-CH (46) } \\
\text { Crytogenic CLD (54) }\end{array}$ & $\begin{array}{l}21(46 \%)^{\star} \\
45(83 \%)^{\star}\end{array}$ & $\begin{array}{l}14(67 \%) \\
40(89 \%)\end{array}$ & $\begin{array}{l}18 / 21(86 \%) \\
43 / 45(96 \%)\end{array}$ \\
\hline
\end{tabular}

^Type-1 AI-CH vs cryptogenic CLD: $\mathrm{p}<0 \cdot 0001\left(\chi^{2}\right)$.

$\mathrm{OD}=$ optical density. The RIBA 2 was applied only to ELISA 2 positive sera.
SMA-AA when at least two of the following reactivities were present ${ }^{11}$ : kidney peritubular and glomerular positivity, ${ }^{12}$ actin cables on HEp-2 cells, ${ }^{13}$ counterimmunoelectrophoresis with actin as antigen, positivity of phalloidin treated rat liver cell actin (submembranous deposits of microfilaments at the sinusoidal and biliary portions)." ANA-H were identified on immunomorphological grounds using $\mathrm{HEp}-2$ cells. ${ }^{5}$

ANTIHEPATITIS C VIRUS TESTING

A commercially available ELISA (Ortho HCV ELISA Test System, 2nd generation - ELISA 2) and a recombinant immunoblot assay (Chiron RIBA HCV Test System, 2nd generation RIBA 2) were used to detect antihepatitis $C$ virus according to the manufacturer's instructions at a dilution of $1: 10$ and 1:50, respectively. The RIBA 2 was applied to ELISA 2 positive sera. ELISA 2 positive results were divided into cases with optical density values higher or lower than 3 (the upper limit of the ELISA reader used). Both a qualitative (which peptide was reactive) and semiquantitative (from negative to $>3+$ ) RIBA 2 evaluation were recorded for each non structural (c100-3, c33c, 5-1-1) and the structural (c22-3) peptide.

Sera were stored at $-20^{\circ} \mathrm{C}$ until tested.

\section{STATISTICAL ANALYSIS}

Statistical analysis was performed using the $\chi^{2}$ test with or without Yates' correction, the Fisher's exact test and the Wilcoxon's rank-sum test, each applied according to its own indications.

\section{Results}

Clinical, biochemical, and histological parameters were similar in cases positive for ANA-H and/or SMA-AA - that is, autoimmune chronic hepatitis cases, and cryptogenic cases, apart from serum gamma-globulin concentrations, significantly higher in the former group (Table I).

Results of ELISA 2 and RIBA 2 antihepatitis $C$ virus are reported in Table II. From its analysis it appears that ELISA antihepatitis C virus, although significantly prevalent in cryptogenic chronic liver disease cases $(45 / 54,83 \%)$, were also detected in a substantial proportion of autoimmune chronic hepatitis cases (21/46, $46 \%)$. ELISA optical density values were higher in the cryptogenic group ( $89 \%$ over the upper limit of the ELISA reader) than in the autoimmune chronic hepatitis $(67 \%)$. The difference, however, was not statistically significant. The vast majority of the ELISA 2 positive sera was also RIBA 2 positive, apart from two sera in the cryptogenic and three in the autoimmune group. Antibodies to $\mathrm{c} 33 \mathrm{c}$ were significantly more frequent in the cryptogenic $(43 / 43,100 \%)$ than in the autoimmune RIBA 2 positive patients (eight of 18,44\%; p <0.000001). By contrast, antibodies to the other peptides were similarly distributed. The comparison of the scores of positivity for each RIBA 2 peptide showed 
TABLE III Antihepatitis $C$ virus antibodies detected by ELISA 2 and RIBA 2 in type-1 autoimmune chronic hepatitis (AI-CH) according to the autoantibody pattern.

\begin{tabular}{|c|c|c|c|}
\hline & \multicolumn{2}{|l|}{ Elisa 2} & \multirow{2}{*}{$\begin{array}{l}\text { RIBA } 2 \\
\text { Anti-HCV+ }\end{array}$} \\
\hline & Anti-HCV+ & $O D>3$ & \\
\hline $\begin{array}{c}\text { AI-CH SMA-AA }+(21) \\
\text { AI-CH ANA-H }+(17) \\
\text { AI-CH SMA-AA+ }+(8) \\
\text { ANA-H }+\end{array}$ & $\begin{array}{l}11(52 \%)^{\mathrm{a}} \\
10(59 \%)^{\mathrm{b}} \\
0^{\mathrm{c}}\end{array}$ & $\begin{array}{l}7(64 \%) \\
7(70 \%) \\
-\end{array}$ & $\begin{array}{l}8 / 11(70 \%) \\
10 / 10(100 \% \\
-\end{array}$ \\
\hline
\end{tabular}

c $v$ a: $\mathrm{p}<0.02$ (Fisher

$c v b: \mathrm{p}<0.01$ (Fisher)

$\mathrm{c} v \mathrm{a}+\mathrm{b}: \mathrm{p}<0.005$ (Fisher

ANA-H $=$ antinuclear antibodies with homogeneous pattern;

SMA-AA = smooth muscle antibodies with anti-actin specificity;

OD=optical density. The RIBA 2 was applied only to ELISA 2

positive sera.

significantly higher values in the cryptogenic than the autoimmune group only for $\mathrm{c} 33 \mathrm{c}$ and c22-3 ( $\mathrm{p}<0.05$ and $\mathrm{p}<0.001$, respectively).

Results of ELISA 2 and RIBA 2 antihepatitis $C$ virus prevalence according to the autoantibody pattern (ANA-H, SMA-AA or both) are given in Table III. By ELISA 2, the prevalence of antihepatitis $C$ virus positivity was similar in the subgroups with isolated ANA-H or SMA-AA; by contrast, all the eight patients positive for both SMA-AA and ANA-H were antihepatitis $C$ virus negative. The three autoimmune cases positive by ELISA 2 and negative by RIBA 2 were all in the SMA-AA subgroup.

The relevant clinical, biochemical, and histological data of autoimmune patients, divided according to the antihepatitis $\mathrm{C}$ virus and autoantibody status, are reported in Table IV. From its analysis it appears that the eight antihepatitis $\mathrm{C}$ virus negative patients with both ANA-H and SMA-AA had significantly higher values of serum gamma globulins than those with either ANA-H or SMA-AA, irrespectively to the antihepatitis $C$ virus result. Moreover, they were all women, had a lower age and higher serum glutamic oxalo acetic transaminase concentrations. These differences, however, did not reach statistical significance.

\section{Discussion}

Apart from the recognition and prevention of non-A-non-B post transfusion hepatitis, the availability of reliable tests for the demonstration of circulating antibodies to hepatitis $\mathrm{C}$ virus peptides has made it possible to address a

TABLE IV Clinical, biochemical and histological parameters in type-1 autoimmune chronic hepatitis (AI-CH): a comparison according to the anti-HCV (searched for by ELISA 2) and autoantibody status

\begin{tabular}{|c|c|c|c|}
\hline & $\begin{array}{l}\text { AI-CH } \\
\text { anti-HCV neg } \\
\text { ANA-H or SMA-AA } \\
\text { (17) }\end{array}$ & $\begin{array}{l}\text { AI-CH } \\
\text { anti-HCV neg } \\
\text { ANA-H and } S M A-A A \\
(8)\end{array}$ & $\begin{array}{l}A I-C H \\
\text { anti-HCV pos } \\
\text { ANA-H or SMA-AA } \\
(21)\end{array}$ \\
\hline Male/female & $3 / 14$ & $0 / 8$ & $4 / 17$ \\
\hline Age $(y r)$ & $57(21-77)$ & $41(15-76)$ & $63(48-81)$ \\
\hline GOT $(\mathbf{U} / \mathbf{l})$ & $51(2+-163)$ & $125(15-620)$ & $39(18-130)$ \\
\hline Gamma-globulins ( $\mathrm{g} / \mathrm{dl}$ ) & $1 \cdot 94(1 \cdot 1+2 \cdot 48)$ & $2 \cdot 60(2 \cdot 00-4 \cdot 27) \dagger$ & $2 \cdot 04(0 \cdot 88-3 \cdot 04)$ \\
\hline Cirrhosis $^{\star}$ & $5 / 9$ & $4 / 6$ & $9 / 14$ \\
\hline
\end{tabular}

^Patients with histological evidence of cirrhosis/patients who underwent liver biopsy. to anti-HCV neg ANA-H or SMA-AA: $<<0 \cdot 006$ (Wilcoxon

$v$ anti-HCV pos ANA-H or SMA-AA: $\mathrm{p}<0.01$ (Wilcoxon).

ANA-H $=$ antinuclear antibodies with the homogeneous pattern. SMA-AA $=$ smooth muscle
antibodies with anti-actin specificity. Values are expressed as median (range). Normal ranges of (GOT antibodies with anti-actin specificity. Values are expressed as median number of yet unresolved problems as the aetiology of cryptogenic chronic liver disease and the role of hepatitis $C$ virus in cases with other known risk factors (hepatitis B virus, alcohol).

Of particular interest is the relationship between autoimmune chronic hepatitis and hepatitis $\mathrm{C}$ virus infection. This study, carried out in an Italian series of patients accurately selected for the absence of other known aetiologic factors, and the presence of well established serum markers of autoimmunity, confirms previous observations made with a first generation ELISA ${ }^{x y}$ that a wide overlap between the two above conditions does occur. Using a second generation ELISA (which allows to detect antibodies to both non-structural and structural peptides), antihepatitis $\mathrm{C}$ virus prevalence in type-1 autoimmune chronic hepatitis, although significantly lower than that of cryptogenic chronic liver disease cases, was still as high as $46 \%$. It is pertinent to recall that an even higher antihepatitis $\mathrm{C}$ virus prevalence has been found in type-2 (liver-kidney microsomal positive) autoimmune chronic hepatitis. ${ }^{1+}$ Moreover, two thirds of the liver-kidney microsomal positive cases had serum hepatitis $C$ virus-RNA, as judged from the positivity of sensitive 'nested' PCR. ${ }^{15}$ The fact that most ELISA 2 positive cases here detected, both in autoimmune chronic hepatitis and cryptogenic chronic liver disease, were also reactive by RIBA 2 confirms the true immune nature of the antihepatitis $C$ virus result. It is difficult to interpret the higher RIBA 2 frequency of anti $c 33 c$ and the higher RIBA 2 scores of both anti $c 33 c$ and c22-3 antibodies in the cryptogenic group, as information on the temporal sequence and significance of the immune response to each viral peptide is lacking at present.

From the above results it appears that the positivity of either ANA-H or SMA-AA, although significantly associated with signs of marked immune stimulation (higher hypergammaglobulinemia Table I), does not allow to rule out a coexistent hepatitis $C$ virus infection.

Interestingly, however, none of the eight cases with both ANA-H and SMA-AA was antihepatitis $C$ virus positive by ELISA 2: this was significantly different from that found in cases positive for either reactivity (ANA-H or SMAAA). If confirmed in a larger number of cases, this would support the hypothesis that the above autoimmune profile is particularly relevant in the positive diagnosis of autoimmune chronic hepatitis. In line with this hypothesis, classical features of autoimmune hepatitis were predominant in these eight patients: female sex, young age, high glutamic oxalo acetic transminase and gamma globulin levels (Table IV). In a recent Italian study with first generation antihepatitis $C$ virus assays, a complete response to steroid therapy occurred only in autoimmune chronic hepatitis patients negative for antihepatitis C virus, ${ }^{16}$ as are the cases with both ANA-H and SMA-AA reported here.

A high hepatitis $C$ virus circulation (in Italy the prevalence of blood donors positive for antihepatitis $\mathrm{C}$ virus ranges from 0.68 to $1.38 \%)^{1}$ could well account for the high prevalence of antihepatitis $C$ virus in our series of chronic liver 
disease with unknown aetiology (66 of 100): of the 66 antihepatitis $\mathrm{C}$ virus positive cases, however, only 21 were positive for the autoantibodies currently considered as reliable markers of autoimmune hepatitis. This rules out the possibility that autoantibodies are merely a consequence of hepatitis $C$ virus infection. In fact, ANA-H and SMA-AA are vitually absent in patients with post transfusion non-A-non-B hepatitis. ${ }^{1819}$ The above discrepancy would be overcome postulating the existence of a genetic predisposition to mount an abnormal autoimmune response, possibly linked to particular HLA alleles (HLA-DR3 ?), known to be significantly prevalent in autoimmune hepatitis. ${ }^{20} \mathrm{HLA}$ typing is now being done in the present series of patients. According to this hypothesis hepatitis $\mathrm{C}$ virus infection would be able to induce hepatitis and, in particular hosts, to trigger an autoimmune response with the release of autoantibodies indistinguishable, at least with the available immunomorphological techniques, from those found in 'primary' autoimmune hepatitis. It is worthwhile to recall that the specificity of the viral attack seems to be another important variable, as ANA-H and SMA-AA are exceedingly rare in chronic liver disease induced by hepatitis B virus, ${ }^{513}$ while a peculiar autoantibody profile has been reported in hepatitis $\mathrm{D}$ virus chronic liver disease. ${ }^{21} 22$

Finally, the use of serum autoantibodies in the diagnosis of autoimmune hepatitis is different according to the different hepatitis $\mathrm{C}$ virus circulation in each geographic area ${ }^{23}$ : of moderate value in the Mediterranean area, with high hepatitis $\mathrm{C}$ virus prevalence, they maintain a definite relevance in areas, such as the UK, with low viral impact.

Part of this work has been published in abstract form in $\mathcal{F}$ Hepato 1991; 13 (suppl 2): S108.

1 Sherlock S. Classifying chronic hepatitis. Lancet 1989; ii: $1168-70$.

2 Mackay IR. Immunological aspects of chronic active hepatitis. Hepatology 1983; 3: 724-8.

3 Gurian LE, Rogoff TM, Ware AJ, Jordan RE, Combes B,
Gilliam JN. The immunologic diagnosis of chronic active 'autoimmune' hepatitis: distinction from systemic lupus erythematosus. Hepatology 1985; 5: 397-402.

4 Cassani F, Fusconi M, Bianchi FB, et al. Precipitating antibodies to rabbit thymus extractable antigens in chronic antibodies to rabbit thymus extractable antigens in chronic Clin Exp Immunol 1987; 68: 588-95.

5 Cassani F, Bianchi FB, Lenzi M, Volta U, Pisi E. Immunomorphani F, Bianchi FB, Lenzi M, Volta U, Pisi E. Immuno-
mogical characterization of antinuclear antibodies in morphological characterization of antinuclear antib
chronic liver disease. $\mathcal{F}$ Clin Pathol 1985; 38: 801-5.

6 Whittingham S, Morstyn G, Wilson JW, et al. An autoantibody reactive with nuclei of polymorphonuclear neutrophils: a cell differentiation marker. Blood 1981; 58: 766-71.

7 Kuo G, Choo QL, Alter HJ, et al. An assay for circulating antibodies to a major etiologic virus of human non-A, non-B hepatitis. Science 1989; 244: 362-4.

8 Cassani F, Ballardini G, Fusconi $M$, et al. Anti-HCV antibodies detected by ELISA in autoimmune and cryptogenic chronic liver disease. F Hepatol 1991; 12: 269-70.

9 Esteban II, Esteban R, Viladomiu L, et al. Hepatitis C virus antibodies among risk groups in Spain. Lancet 1989; ii: $294-7$.

10 Leevy CM, Popper H, Sherlock S. Diseases of the liver and biliary tract. Standardization of nomenclature, diagnostic criteria and diagnostic methodology. Chicago: Year Book Medical Publishers, 1976.

11 Fusconi M, Cassani F, Zauli D, et al. Anti-actin antibodies: a new test for an old problem. F Immunol Methods 1990; 130: $1-8$.

12 Bottazzo GF, Florin-Christensen A, Fairfax A, Swana G, Doniach D, Gröeschel-Stewart U. Classification of smooth muscle autoantibodies (SMA) detected by immunofluorescence. 7 Clin Pathol 1976; 29: 403-10.

13 Pedersen JS, Toh BH, Mackay IR, et al. Segregation of autoantibody to cytoskeleton filaments, actin and intermediate filaments, with two types of chronic active hepatitis. ate filaments, with two types of
Clin Exp Immunol 1982; 48: 527-32.

14 Lenzi M, Ballardini G, Fusconi M, et al. Type 2 autoimmune hepatitis and hepatitis $C$ virus infection. Lancet 1990; 335: 258-9.

15 Garson JA, Lenzi M, Ring C, et al. Hepatitis C viraemia in adults with type 2 autoimmune hepatitis. F Med Virol 1991; 34: 223-6.

16 Magrin S, Craxì A, Fiorentino G, et al. Is autoimmune chronic active hepatitis a HCV-related disease? F Hepatol 1991; 13: 56-60.

17 Sirchia G, Bellobuono A, Giovanetti A, Marconi M. Antibodies to hepatitis $\mathrm{C}$ virus in Italian blood donors. Lancet 1989; ii: 797.

18 Mackay IR, Frazer IH, Toh BH, Pedersen JS, Alter HJ Absence of autoimmune serological reactions in chronic Absence of autoimmune serological reactions in chronic
non-A, non-B viral hepatitis. Clin Exp Immunol 1985; 61: non-A,

19 Cassani F, Tremolada F, Baffoni L, et al. Markers of 'viral' autoimmunity in chronic non-A, non-B post-transfusion hepatitis. Ital f Gastroenterol 1988; 20: 171-4.

20 Mackay IR, Whittingham S, Mathews JD, et al. Genetic determinants of autoimmune chronic active hepatitis. Springer Semin Immunopathol 1980; 3: 285-96.

21 Crivelli O, Lavarini C, Chaberge E, et al. Microsomal autoantibodies in chronic infection with the HBsAg associated delta agent. Clin Exp Immunol 1983; 54: 332-8.

22 Zauli D, Fusconi M, Crespi C, Bianchi FB, Crazì A, Pisi E. Close association between basal cell layer antibodies and hepatitis B virus-associated chronic delta infection. Hepatology 1984; 4: 1103-6.

23 Lenzi M, Johnson PJ, McFarlane IG, et al. Antibodies to hepatitis $C$ virus in autoimmune liver disease: evidence for geographical heterogeneity. Lancet 1991; 338: 277-80. 